\title{
Jazyková poradna v měnící se komunikační situaci u nás
}

\author{
LUDMILA UHLÍŘOVÁ* \\ Ústav pro jazyk český AV ČR Praha
}

\section{Language Services in the Light of Recent Communication Changes in the Czech Republic}

\begin{abstract}
Language consulting services provided by the Czech Language Institute in Prague represent a form of academic, i.e. institutionally organised, care for language. The main task of the Institute is to answer questions about language asked by lay and professional users of the language. People who have language problems and wish to obtain information about their mother tongue may call, write, or personally visit the Language Service. People can pose a variety of questions, e.g. how to spell or pronounce a word, what the meaning of a word, phrase or sentence is, how to use a word, and what its origin is, and many other questions concerning the specific problems of everyday linguistic practice. The linguists provide responses, offer advice, recommendations, and explanations, and they provide linguistic reasons for language facts. The article shows that the questions concern the most varied aspects of language use. People from different professional and social groups seek out the Institute's advice, and a correlation exists between the topics of their questions and their professions. The role of the Language Services under the current social situation is also discussed.
\end{abstract}

Sociologický časopis/Czech Sociological Review, 2002, Vol. 38, No. 4: 443-455

\section{Jazyková poradna}

České jazykové poradenství reprezentované pražskou jazykovou poradnou Ústavu pro jazyk český AV ČR je akademickou, tedy institucionální formou péče o češtinu. Jazykoví uživatelé - laická i odborná veřejnost - mají možnost obracet se na jazykovědce s dotazy o konkrétních problémech, s nimiž se setkávají ve své každodenní jazykové praxi. Mohou například požádat o radu, jak napsat nebo vyslovit nějaké slovo, zeptat se, jak se má skloňovat nějaké podstatné jméno či časovat sloveso, co nějaké slovo nebo slovní spojení znamená a zda je ho vhodně užito v nějakém kontextu, jaký je původ slova, $\mathrm{z}$ kterého jazyka je do češtiny přejato atd. atd. Dotazů přichází velmi mnoho, a jak dále ukážeme, týkají se nejrůznějších stránek uživání jazyka, přicházejí od různých profesních a sociálních skupin jazykových uživatelů a rozmanité jsou i okolnosti a motivy, které tazatele vedou k položení dotazu.

Jazykovědci odpovídají: radí, doporučují, vysvětlují, zdůvodňují - a očekávají, že tazatelé jejich rady přijmou. Nemají však žádnou pravomoc cokoli nařizovat či naopak zakazovat, přestože jsou o to čas od času i velmi důrazně žádáni. Na rozdíl od některých jiných evropských zemí v české společnosti nikdy neexistoval a ani dnes, v době mohutných globalizačních procesů, neexistuje parlamentem schválený jazykový zákon, jehož obsahem by byla ochrana českého jazyka jako jednoho ze základních prvků národní identity a kte-

\footnotetext{
* Veškerou korespondenci posílejte na adresu: PhDr. Ludmila Uhliřová, CSc., Ústav pro jazyk český AV ČR, Letenská 4, 11851 Praha, e-mail: uhlirova@ujc.cas.cz
} 
rý by právně ochraňoval a tím i reguloval určitý způsob uživání jazykových prostředků v určitých oblastech veřejné komunikace. Za jazykové chyby nelze tedy v tomto smyslu nikoho sankcionovat (s výjimkou školní praxe, kde ovšem žák za chybu v diktátu dostane sníženou známku). Nelze tedy např́íklad nikoho násilím nutit, aby jako účastník veřejné, oficiální komunikace mluvil výhradně spisovně. Ani Slovník spisovné češtiny pro školu a veřejnost [2000], ani Pravidla českého pravopisu [1999] nejsou prezentovány jako striktní předpisy, ale spíše jako doporučení řídící se zčásti zjištěným územ v textech určených veřejnosti a nabízející v řadě případů i pravopisné a tvarové varianty.

Úlohou jazykové poradny je být jakousi „první pomoci““, kterou poskytuje vědecký ústav široké veřejnosti. Činí tak nepřetržitě již od svého založení v r. 1946 - tedy více než půl století. Za tuto dobu si veřejnost na služby jazykové poradny zvykla, vnímá poradnu jako autoritu v jazykových otázkách, jako nositele určité linie v jazykové výchově a jazykové politice (v jazykovém „managementu“, jazykové regulaci) a cení ji jako významnou a potřebnou kulturní hodnotu.

Pracovníci jazykové poradny jsou veřejnosti k dispozici každý pracovní den dvě hodiny na speciální telefonní lince, vedle toho odpovídají na dopisy došlé poštou a od r. 1999, kdy ústav získal připojení $\mathrm{k}$ internetu, radí také též po internetu. Internetová poradna je dnes výrazně převažující písemnou formou styku s veřejností. Součástí internetové jazykové poradny je rovněž průběžně budovaná stránka odpovědí na časté typy dotazů. Obsahuje poučení týkající se např. pravopisné shody podmětu a př́ísudku (úřad a město se dohodly), poučení o psaní velkých písmen v názvech veřejných prostranství začínajících předložkou (ulice Na Rybníčku, Ve Strži,..., v jejichž pravopisu došlo v Pravidlech českého pravopisu z r. 1993 k sjednocující úpravě), dále výklad významů, výslovnosti, pravopisu a skloňování některých slov nově přjejímaných do češtiny (franšiza, hardware, software,...) - a konečně i některé „evergreeny“ ze školních lavic (například pravopisně neřešitelnou hříčku Na bidle si kos udělal bydlo. Zafoukal vítr a obě b-dla spadla.). Webová stránka poradny je dnes již rozsáhlá (www. ujc.cas.cz/poradna/Na co se nás často ptáte), setkává se s př́znivým ohlasem veřejnosti a výběr z odpovědí se dočkal svého prvního knižního vydání [Černá, Svobodová, Šimandl, Uhlířová 2002].

Mnoho dotazů je rutinních. Tazatelé by odpovědi snadno nalezli, kdyby nahlédli do běžných prŕíruček „pro školu a veřejnost“, například do jednosvazkového Slovníku spisovné češtiny nebo do Pravidel českého pravopisu, jejichž školní vydání je zařazeno do seznamu učebnic pro základní školy. Při odpovídání na takové dotazy by práci poradny velmi usnadnilo zpř́ístupnění některých existujících jazykových příruček na internetu, popř. vytvoření speciální příručky elektronické, vyhovující novému způsobu komunikace po internetu.

\section{Jazyková situace}

Jazyková poradna je dialog jazykovědců s veřejností, a má tedy, jako každý dialog, dvě stránky, resp. dvojí směr: lingvisté poskytují veřejnosti odborné rady o užívání češtiny a zároveň se z jazykových dotazů, které jsou jim kladeny, dozvídají empirické informace, kterých pak mohou využít i v jazykové teorii. Získávají aktuální svědectví o tom, jak vypadá „nejsoučasnější “ čeština, jak se proměňuje, vyvijí, kde jsou „slabá místa“ jazykového systému, a v neposlední řadě i o tom, jaké jsou postoje uživatelů ke stavu jazyka, k vývojovým proměnám a $\mathrm{k}$ mateřskému jazyku vůbec a jak se projevují v jejich jazykovém chování. 
Není pochyb o tom, že taková zpětná vazba mezi lingvisty a veřejností je velmi důležitá. Vždyt’ každá výpověd', která je pronesena, je nejen mluvním aktem, ale zároveň aktem sociálním. Tak jak se vyvijí společnost, tak se proměňuje i jazyk, společností užívaný a prožívaný. Jaká je dnešní společnost a její jazyk? K atributům, jimiž je snad nejčastěji charakterizován vývoj dnešní společnosti, nejen ovšem společnosti české, nýbrž společnosti světové, patří globalizace a komputerizace. Obrovský rozvoj vědy a komunikačních médií včetně internetu mění dosavadní moderní společnost ve společnost, která bývá nazývána kybernetickou („cybersociety“) a postmoderní. Na jeden z význačných rysů dnešní společnosti poukázal J. V. Neustupný [1999:282]: „,...a modern society requires strong adherence to norms. In a postmodern society variation in norm does not matter to the same extent." Do jaké míry tvrzení Neustupného platí o normách lidského chování (o normách komunikačních), je otázkou pro sociology. Pokud jde o normy jazykové, je zcela zřetelné, že česká spisovná norma oslabuje, a lingvisté na to dlouhodobě, opakovaně a často poukazují. Píší o „rozmělňování“, „decentralizaci“, „rozvolňování“, „relativizaci“, „liberalizaci“ spisovné normy, o „Znejasňováni““ jejích hranic a o oslabování prestiže a míry ovládání spisovné normy (resp. šíře: prestižní variety) u některých sociálních skupin [Aktuální... 1979, Daneš 1996, Daneš 1999, Čeština... 2000, Dynamika... 1988, Havránek 1979, Hlavsa 1996, Jedlička 1978, Jelínek 1996, Kraus et al. 1981, Krčmová 2000, Kultura... 1969, Nebeská 1996, Nekvapil 2000, Palková 1995, Rusínová 2000, Sgall, Hronek 1992, Spisovná... 1995, Spisovnost... 1996, Stich 1969, Stich 1995]. Rozpětí funkční adekvátnosti jazykových prostředků se rozšiřuje, otevírá se směrem k větší toleranci vůči hovorovým, až substandardním prostř̌edkům v komunikačních situacích dříve považovaných za spisovné.

Lingvisté vysvětlují, že na tuto situaci spolupůsobí celá řada činitelů. Z nich za nejdůležitější považují dva. Zaprvé je to historicky daná existence specificky českého typu diglosie. Diglosií se tu nazývá nesoulad mezi češtinou kodifikovanou a češtinou každodenního neoficiálního styku, rozšířenou na velké části území, ale nekodifikovanou, projevující se na rovině hláskoslovné, morfologické - celej tejden, lidi se divaj, i např́iklad v jevech slovní zásoby. Zadruhé je to fakt, že rozvoj komunikačních médií a vědecký pokrok vůbec staví mluvčího do zcela nových, mnohotvárných komunikačních situací; to ovlivňuje rozvoj registrů, žánrů a stylů. Problém je v tom, že sama opozice pojmů veřejná a neveřejná komunikace se různě posouvá: Jestliže např́iklad televizní redaktor vede „neformální“ rozhovor se svými hosty, pak neformálnost se projevuje nejen např. samým uspořádáním televizní „scény“a někdy např. tím, že svým hostům tyká, ale také tím, že rozhovor bývá uveden zpravidla češtinou (více či méně) spisovnou, ale ve vlastní prrímé řeči slyšíme jak v replikách hostů, tak nezrrídka i v replikách redaktorových/moderátorových zřetelné (více či méně výrazné) jazykové prostředky takové, které lingvisté nazývají hovorové (tj. ještě spisovné, ale charakteristické spíše pro projevy mluvené než psané), až i výrazně substandardní. Takový dialog je sice záměrně stylizován jako neformální, ale je vysílán - je určen veřejnosti a sledován veřejností. Je to tedy dialog patřící svou funkcí do sféry veřejné, mediální komunikace. V této sféře byla dosud tradičně očekávána/preferována/předpokládána spisovnost.

Není cílem tohoto článku analyzovat současnou jazykovou situaci u nás, ale bylo nutné se o ní alespoň stručně zmínit proto, aby bylo zřejmé, za jaké situace dnešní jazyková poradna pracuje. To, jací jsou její klienti, jaké jsou jejich jazykové problémy a jaké postoje k jazyku vyjadřují, vyplývá právě z dnešní jazykové situace. Je třeba přitom zdůraznit, že spisovná čeština jakožto soustava obecně přijatých vyjadřovacích prostředků a způ- 
sobů jejich uživání není defektní. Je to plně funkční celonárodní útvar, schopný plnit všechny komunikační potřeby vzdělaného mluvčího. Její systém není ani rozkolísaný, ani neúplný.

\section{Poradenská databáze}

Dříve než uvedeme konkrétní statistické údaje o tazatelích jazykové poradny a o četnostech jejich jazykových dotazů, je třeba upozornit, že agenda jazykové poradny jako zdroj sociolingvistické informace má svá omezení: Jen někteří lidé píší dopisy a e-maily, a ti, kteří je píší, nemohou být považováni za prokazatelně reprezentativní vzorek celé populace. Z hlediska sociolingvistického je důležité, že psaní dopisů, posílaných obyčejnou nebo elektronickou poštou, je subjektivní způsob komunikace: V dopisech se manifestuje individuální jazykové povědomí, jednotlivcův postoj $\mathrm{k}$ jazyku a řeči. S tím je nutno při hodnocení tohoto informačního zdroje počítat.

Dopisy od veřejnosti jsou srovnatelné s jiným populárním způsobem vedení dialogu mezi lingvisty a nelingvistickou částí veřejnosti, totiž s anketami (dotazníky). Zatímco v anketách klade otázky lingvista, v dopisech stejně jako v telefonátech je směr otázky obrácený, iniciativa přichází přímo od uživatelů jazyka, a není tedy dotčena lingvistovým záměrem. Nicméně jak v dotaznících, tak v dopisech se tazatelův sdělovaný postoj může odchylovat od jeho spontánní jazykové praxe, takže v tomto ohledu jsou obě „techniky dialogu“ s veřejností nedokonalé.

Empirické údaje o poradenských dokumentech jsou snadno dostupné z databáze, která je o nich soustavně vedena již od roku 1992. Databáze obsahuje podrobné informace o všech dopisech a faxech došlých do poradny od ledna roku 1992 a o odpovědích pracovníků poradny na ně. Výběrově jsou dokumentovány telefonické odpovědi a od roku 1999 elektronické dotazy spolu s odpověd’mi. Hlavním kritériem zařazení telefonického nebo elektronického dotazu a odpovědi do databáze je to, zda v okamžiku odpovídání je, anebo není po ruce běžná, rutinní odpověd'. Nerutinní odpověd', uložená v databázi, může být později vyhledána a využita, kdykoli poradna obdrží stejný dotaz. Zaznamenávat odpovědi na všechny telefonické a elektronické dotazy zatím nelze; technická náročnost kompletních záznamů by obrovským způsobem převýšila současné personální možnosti pracoviště.

Dílčí lingvistické a sociolingvistické analýzy databázového materiálu byly již publikovány v řadě článků [Černá 1999, Svobodová 1999, Svobodová 2000, Šimandl 2000, Uhlířová 1996, Uhlířová 1998a, Uhlírová 1998b, Uhlířová 1999a, Uhliŕrová 1999b, Uhliřová 2001]. V tomto článku chceme (a) shrnout, co databáze jazykové poradny přinesla jazykovým uživatelům i lingvistům za desetileté období (přesněji: za období 1. 1. 1992 - 1. 9. 2001), a (b) porovnat tradiční dopisovou formu poradenství s elektronickou. Ta představuje zcela nový způsob komunikace s tazateli, výrazně ovlivňuje organizaci práce v poradně a v neposlední řadě vede i ke vzniku nového elektronického žánru, jímž e-mailová odpověd’ na jazykový dotaz bezesporu je.

Za uvedené období odpověděli pracovníci jazykové poradny celkem na 1043 dopisů, v nichž bylo položeno celkem 1563 jazykových dotazů (nejdelší dopis obsahoval sedmnáct dotazů). Od r. 1999, kdy se postupně rozbíhala internetová jazyková poradna, došlo (k 1. záŕí 2001) více než 4000 elektronických dopisů, z nichž některé rovněž obsahovaly více než jeden jazykový dotaz. Z nich 819 e-mailů, obsahujících celkem 993 jazykových do- 
tazů, bylo zařazeno do databáze. Statistické údaje, které budou uvedeny dále, jsou úplným souborem dat ze všech dopisů za celé uvedené období a dále ze všech těch e-mailů, které byly pojaty do databáze. Stranou pozornosti ponecháváme v tomto článku dotazy telefonické.

Z hlediska sociolingvistického je relevantní to, že dlouholetá poradenská zkušenost dokázala nade vši pochybnost, že nelze tvrdit, že by některé skupiny tazatelů produkovaly jen/více/spíše dotazy rutinní a jiné skupiny tazatelů jen/více/spíše dotazy nerutinní. Ve všech tazatelských skupinách rutinní dotazy početně vysoce převažují nad nerutinními, takže není nebezpečí, že by v databázových záznamech byly některé skupiny signifikantním způsobem podhodnoceny a druhé naopak nadhodnoceny. Dosavadní databázové záznamy představují první způsob počítačového zpracování poradenských dat. S postupující elektronizací poradenské práce se počítá v budoucnu s rozšířením a zdokonalením počítačových záznamů.

\section{Kdo jsou tazatelé jazykové poradny}

Tabulka 1 podává přehled o tom, s jakým množstvím dotazů se tazatelé z různých profesních a sociálních skupin obracejí na jazykovou poradnu jednak klasickou, jednak elektronickou poštou. Pro databázové účely bylo nutno všechny tazatele (jednotlivce a instituce) předem klasifikovat do rozumného počtu skupin. Počet skupin byl zvolen na základě předchozích zkušeností z poradenské praxe tak, aby pokud možno odrážel také rozdílné profesní potřeby jednotlivých skupin při zacházení s jazykem, pokud jsme schopni je z dotazu identifikovat. Zvolené třídění není jediné možné a mezi jednotlivými skupinami jsou neostré hranice. Zdůvodnění daného třídění spolu s konkrétními prríklady je uvedeno jinde [Uhlírová 1996]. Zopakujme zde, že například jednotliví učitelé kladou otázky týkající se zcela konkrétních pravopisných problémů vznikajících při školní výuce, jako je např̀. spor o $i / y$ při shodě podmětu a prrísudku nebo $\mathrm{v}$ tvarech přivlastňovacích přídavných jmen. Naproti tomu obdržíme-li dotaz od školy jakožto instituce (s razítkem školy, na hlavičkovém papíře, většinou s názvem školy v prvním řádku adresy), týká se spíše provozu školy (např. interpunkce v dohodě o pracovní činnosti, velkých/malých písmen v názvu školy nebo v adrese či informací o odborné literatuře).

Co ukazují data v tabulce 1 ?

Především je vidět, že různé skupiny tazatelů se obracejí na jazykovou poradnu různě často. Přibližně polovinu všech tazatelů tvoří heterogenní skupina soukromých nebo profesně neidentifikovaných tazatelů, tj. takových, v jejichž dopisech a e-mailech je bud' výslovně deklarován osobní, „soukromý“ zájem o řešení daného jazykového problému, anebo těch, u nichž nelze na motivaci dotazu ze znění dopisu jednoznačně usuzovat. Druhou polovinu tvoří ti tazatelé, které můžeme souhrnně nazvat profesionálními jazykovými uživateli. Jsou to ti, kteří - na rozdíl např̀. od luštitele kř́žovky nebo toho, kdo pátrá po původu svého prŕijmení či po původu názvu své rodné obce - nepotřebují znát odpověd’ na jazykový dotaz jen „pro sebe“. Jsou to naopak tazatelé, jejichž dotazy nějakým způsobem souvisejí s jejich profesní rolí ve veřejné komunikační oblasti, např. s fungováním nějaké instituce či s povoláním jednotlivce (u žáků, studentů s př́ipravou na povolání), a kteří tudíž odpověd' jazykové poradny dále šiří, napřr. učitel ve škole, redaktor v novinách, podnikatel v obchodní korespondenci apod., a tím ovlivňují další jazykové uživatele, např. čte- 
Tab. 1. Kdo jsou tazatelé jazykové poradny a kolik dotazů jí adresují. Celkový přehled.

\begin{tabular}{lrrrr} 
tazatelská skupina/počet dotazů & \multicolumn{2}{c}{ v dopisech } & \multicolumn{2}{c}{ v e-mailech } \\
& četnost & 50,51 & 521 & 54,27 \\
\hline soukromí/neidentifikovaní tazatelé & 790 & 0,19 & 5 & 0,52 \\
anonymní tazatelé & 3 & 3,13 & 3 & 0,31 \\
právníci & 49 & 1,66 & 24 & 2,50 \\
sekretářky & 26 & 5,56 & 52 & 5,42 \\
učitelé, profesoři všech stupňů škol & 87 & 7,03 & 71 & 7,40 \\
novináŕi, redaktoři, korektoři & 110 & 2,37 & 22 & 2,29 \\
spisovatelé, překladatelé & 37 & 3,07 & 46 & 4,79 \\
žáci, studenti, jejich (pra)rodiče & 48 & 0,77 & 10 & 1,04 \\
soukromí podnikatelé & 12 & 5,43 & 93 & 9,69 \\
individuální tazatelé různých profesí & 85 & 5,24 & 27 & 2,81 \\
společnosti typu s. r. o., a. s. aj. & 82 & 3,26 & 29 & 3,02 \\
ostatní instituce & 51 & 6,97 & 28 & 2,92 \\
obecní aj. úřady státní správy & 109 & 1,85 & 1 & 0,10 \\
soudy, policie & 29 & 1,98 & 7 & 0,73 \\
školy všech typů & 31 & 0,96 & 21 & 2,19 \\
nakladatelství, tiskárny, rekl. agent. & 15 & 100,00 & 960 & 100,00 \\
\hline celkem & 1564 & & &
\end{tabular}

náře novin. Skutečnost, že polovina tazatelů jsou prokazatelně profesionální jazykoví uživatelé s určitou sférou vlivu na další uživatele, považujeme za důležitější než statistické údaje o absolutních četnostech tazatelů poradny. Navíc lze předpokládat, že mezi těmi, kdo při formulaci dotazu nikterak neprojeví motiv dotazu, je rovněž početná skupina těch, jejichž dotazy vznikají v pracovním prostředí.

Porovnáme-li mezi sebou z tohoto hlediska dopisy a e-maily, konstatujeme jen poměrně malý početní nárůst skupiny soukromých/neidentifikovaných tazatelů v e-mailech: proti $51 \%$ v dopisech je to $54 \%$ v e-mailech. Nepotvrzuje se tedy nikterak výrazně to, co se někdy o elektronické komunikaci tvrdivá, že totiž vede $\mathrm{k}$ anonymizaci komunikujících. Je pravda, že všichni tazatelé jsou si rovni v tom, že se povinně představí všichni stejně, svou e-mailovou adresou. $\mathrm{V}$ tomto ohledu jde tedy o komunikaci přirozeně demokratickou, v níž se důraz klade na to, co se odpovídá, spiše než na to, komu se odpovídá. Ale vzhledem $\mathrm{k}$ tomu, že formulace jazykových dotazů jsou velice individuální a specifické jsou i okolnosti, za nichž dotazy vznikají, ani odpovědi různým tazatelům na jeden a týž dotaz, sice obsahově stejné, nemusí mít doslovné znění, ale mohou v nich vystupovat do popředí různá hlediska a mohou být vykládány $\mathrm{z}$ různých perspektiv.

Je ovšem pravda, že v elektronických dopisech jsou běžné „epistolární konvence“ formalizovány - např. údaje o odesílateli, adresátu, předmětu dotazu, dále podpis, datum a čas odeslání. Toto vše je jednotným způsobem předepsáno ve formuláři na obrazovce počítače. (Metatextem tu často je stále ještě angličtina.) Ztrácejí se i všechny extralingvistické rysy, které jsou přitomny v dopisech psaných na papiře, jako je druh dopisního papíru, druh psacího stroje nebo tiskárny, individuální formální úprava dopisu včetně hlavičky, typ 
Tab. 2. Kolik dotazů adresují jazykové poradně ti, kdo potřebují znát odpověd’ pro svou profesní práci

\begin{tabular}{lrrrrcr} 
tazatelská skupina/počet dotazů & \multicolumn{2}{c}{ v dopisech } & tazatelská skupina/počet dotazů & \multicolumn{2}{c}{$\begin{array}{c}\text { v e-mailech } \\
\%\end{array}$} \\
\hline četnost & \multicolumn{1}{c}{$\%$} & & 71 & 17,07 \\
novináři, redaktoři, korektoři & 110 & 14,05 & novináři, redaktoři, korektoři & 73 & 17,55 \\
obecní aj. úřady státní správy & 109 & 13,92 & individuální tazatelé různých profesí & 72 & 14,90 \\
učitelé, profesoři všech stupňů škol & 87 & 11,11 & žáci, studenti, jejich (pra)rodiče & 62 & 13,22 \\
individuální tazatelé různých profesí & 85 & 10,86 & učitelé, profesoři všech stupňů škol & 55 & 36 & 8,65 \\
společnosti typu s. r. o., a. s. aj. & 82 & 10,47 & sekretářky & 22 & 5,29 \\
spisovatelé, překladatelé & 51 & 6,51 & společnosti typu s. r. o., a. s. aj. & 22 & 5,29 \\
právníci & 49 & 6,26 & obecní aj. úřady státní správy & 19 & 4,57 \\
žáci, studenti, jejich (pra)rodice & 48 & 6,13 & ostatní instituce & 14 & 3,37 \\
ostatní instituce & 46 & 5,87 & spisovatelé, překladatelé & 13 & 3,13 \\
školy všech typů & 31 & 3,96 & soukromí podnikatelé & 13 & 3,13 \\
soudy, policie & 29 & 3,70 & nakladatelství, tiskárny, rekl. agent. & 9 & 2,16 \\
sekretářky & 26 & 3,32 & právníci & 6 & 1,44 \\
nakladatelství, tiskárny, rekl. agent. & 15 & 1,92 & školy všech typů & 1 & 0,24 \\
soukromí podnikatelé & 12 & 1,53 & soudy, policie & 0 \\
anonymní tazatelé & 3 & 0,38 & anonymní tazatelé & celkem & 416 & 100,00
\end{tabular}

a velikost fontů, vůně dopisního papíru, u dopisů psaných rukou i rukopis a inkoust. Neztrácí se však individuální jazyková stylizace dopisů a rovněž jsou ve velké míře zachovány všechny základní komponenty epistolárního žánru: oslovení, úvod k dotazu, vlastní dotaz, závěrečná formule a podpis; podrobněji viz [Uhlířová 2001].

$\mathrm{Z}$ dat v tabulce 1 je vidět také to, že dopisy mají své autory. Anonymní dopisy jsou výjimkou a jejich obsahem bývá obecná, expresivně laděná kritika „úpadku“ dnešní češtiny. Naproti tomu e-maily sice musejí formálně mít své odesilatele, ale jejich e-mailová adresa o nich nemusí nic prozrazovat. Problémem, který pracovníky poradny mrzí, je, že se někdy odpověd' poradny vrátí jako nedoručitelná.

Ne všichni tazatelé, které jsme souhrnně nazvali profesionálními, se obracejí na jazykovou poradnu stejně často. Porovnání jednotlivých profesních skupin podle počtu dotazů položených jazykové poradně dostáváme $\mathrm{z}$ tab. 2 , kde jsou vypočítány relativní četností dotazů podle jednotlivých profesních skupin.

Nejčastěji se na jazykovou poradnu obracejí novináŕi, redaktoři a korektoři, a to jak v dopisech (14 \% ze všech dotazů od profesních tazatelů), tak v e-mailech (17 \%). Zdá se, že jedním z důležitých činitelů, které působí na pocit jazykové závaznosti textů, je potenciální počet adresátů, jimž jsou texty - tj. texty určené veřejnosti - adresovány: čím větší je tento počet, třeba počet výtisků novin, knih aj., tím větší je potřeba autorů vyjadřovat se v souladu s jazykovými normami a respektovat kodifikaci. Stejně tak je znalost jazykových norem prestižní otázkou pro autory dokumentů obecních a jiných úřadů státní správy (četnost dopisů od této skupiny tazatelů činí téměř $14 \% \mathrm{z}$ celkového počtu dopisů) a - jak lze očekávat - pro učitele a profesory všech stupňů škol (11 \% ze všech dopisů, 13 \% e-mailů). Naproti tomu pokud se na jazykovou poradnu obracejí soudy, policie či právníci (advokátní kanceláře), pak je to proto, aby mohli odpověd’ poradny využít při řešení konkrétní kauzy. Proto s poradnou korespondují klasickou poštou, e-maily jsou spíše výjimkou a slou- 
ží např. předběžné konzultaci o problému. Soukromé společnosti (typu s. r. o., a. s. aj.) začínají stále více dávat přednost e-mailům (10\%) před klasickou písemnou korespondencí ( $5 \%$ dotazů), a rovněž jejich sekretářky si osvojují e-mail velmi rychle ( $9 \%$ tazatelů). Stále širší dostupnost e-mailu spolu se snadností a pohodlností komunikace po sítích vede $\mathrm{k}$ tomu, že se velmi výrazně zvyšuje například podíl individuálních tazatelů nejrůznějších profesí (více než 17 \%) a rovněž, jak již uvedeno, podíl dotazů od sekretářek, jejichž dotazy bývají tak specifické, že jsme je vyčlenili jako zvláštní tazatelskou skupinu. E-mail preferují studenti a žáci všech stupňů škol i jejich rodiče: absolutní četnost e-mailů, a to - zopakujme - jen těch, které jsou zařazeny do databáze jako nerutinní, převyšuje celkovou četnost všech dopisů došlých od této skupiny tazatelů za posledních deset let (48 dopisů proti 62 e-mailům), a tazatelský podíl této skupiny v porovnání s ostatními skupinami výrazně vzrostl (15\% e-mailujících studentů (žáků, jejich rodičů) proti $6 \%$ dopisujících. Tato společenská skupina využívá e-mailu jako konzultačního média v současné době (zatím?) více než učitelé (ti tvoři $11 \%$ ze všech tazatelů).

Role elektronické pošty v komunikaci jazykové poradny s veřejností nepřetržitě vzrůstá. Je zjevné, že umožňuje působit na stále širší okruh jazykových uživatelů, ale zatím není pravda, že by tradiční písemnou komunikaci zcela nahrazovala - počet dopisů, které obyčejná pošta ročně doručí do jazykové poradny, v průběhu posledních let neklesá, spíše jejich množství poněkud narůstá.

\section{Na co se tazatelé ptají}

Tabulka 3 ukazuje distribuci jazykových zájmů tazatelů jazykové poradny jednak v dopisech, jednak v e-mailech.

Tematicky (obsahově) jsou dotazy utř́iěny do deseti skupin, na dotazy týkající se výslovnosti, pravopisu, tvoření slov, tvarosloví, syntaxe, slovní zásoby, stylistiky, textové struktury, formální úpravy písemností a zbytkové kategorie ostatních dotazů (informace o jazykovědné literatuře aj.). Toto třídění pokrývá hlavní oblasti struktury jazyka a jeho uživání a zároveň vystihuje nejdůležitější okruhy tazatelských zájmů. Jak je z uvedeného třídění zřejmé, jsou tazatelské zájmy širší než problémy týkající se vlastní jazykové „správnosti“. Platí to zejména o dotazech týkajících se formální úpravy písemností, v nichž se tazatelé někdy dožadují „pravidel“ i tam, kde žádná předepsána nejsou nebo která jsou obsahem speciálních administrativních norem pro úpravu písemností apod., tedy těch norem, které vypracovává Český normalizační institut. Jazyková poradna ve svých odpovědích na tyto normy odkazuje. Vývoj přitom ukazuje, že pravopisná kodifikace jazykovědná a norma pro úpravu písemností se v některých bodech překrývají, např. v nepsaní mezer u spojovníků apod.

Z tabulky 3 je vidět, že se tazatelé zajímají především o pravopis a o slovní zásobu: Dotazy pravopisné tvoří 28 \% všech dotazů položených jazykové poradně v dopisech a 33 \% položených v e-mailech, dotazy týkající se slovní zásoby představují - stejně v dopisech jako v e-mailech - 31,5\%.

Pravopis je nejpodrobněji kodifikovanou oblastí jazyka. Je to však oblast, kde se ve velké míře uplatñují konvence. Pravopisné konvence jsou pocitovány jako velmi závazné a takto jsou také prezentovány i školní výukou, kde se pravopisu věnuje velká pozornost. Porušení pravopisných konvencí v psaném textu, zejména tištěném, je vnímáno jako nápadné. Uvedeme několik př́ikladů. Velké množství dotazů se týká shody podmětu a přísudku. Ne- 
Tab. 3. Témata jazykových dotazů a jejich četnosti

\begin{tabular}{lcc} 
Obsah dotazu & $\begin{array}{c}\text { dopisy } \\
\text { četnost } \mathrm{v} \%\end{array}$ & $\begin{array}{c}\text { e-maily } \\
\text { četnost } \mathrm{v} \%\end{array}$ \\
\hline výslovnost & 1,70 & 0,72 \\
pravopis & 27,77 & 32,79 \\
tvoření slov & 6,48 & 7,25 \\
tvarosloví & 9,95 & 15,22 \\
skladba & 8,32 & 2,66 \\
slovní zásoba & 31,43 & 31,66 \\
stylistika & 2,10 & 1,02 \\
textová struktura & 4,91 & 0,92 \\
forma písemnosti & 0,65 & 0,20 \\
jiné & 6,68 & 7,56 \\
\hline celkem & 100,00 & 100,00
\end{tabular}

dorozumění (a pravopisně chybné řešení) vzniká např. tehdy, neuvědomí-li si pisatel textu, že pro shodu podmětu a př́sudku je rozhodující mluvnický, nikoli přirozený (biologický) rod podstatného jména v pozici podmětu, že je tedy třeba psát letci zaútočili na cíl, ale letouny zaútočily na cíl, dále sněhuláci roztáli, ale vlády, parlamenty, úrady, odpovědné osoby rozhodly. Rozsáhlou pravopisnou oblastí je psaní velkých vs. malých písmen v názvech veřejných prostranství, v názvech zeměpisných, $\mathrm{v}$ titulech osob, $\mathrm{v}$ názvech institucí, úřadů a jejich organizačních složek. Problémy jsou s pravopisem přejatých slov (byznys, anebo business?); z domácích slov působí starosti předpony s-/z- (strávit, spřizněný, sleva, ale zlevně$n y ́$...). Dotazy se týkají také uživání interpunkčních znamének, zejména interpunkční čárky v souvětí. Vyšší relativní četnost pravopisných dotazů v e-mailech v porovnání s dopisy svědčí o tom, že u e-mailových dotazů, podobně jako u telefonátů, spoléhá tazatel na rychlost komunikace - na to, že odpověd' dostane pokud možno bezodkladně. Klade proto otázky vznikající z bezprostřední pracovní potřeby, a takovými právě pravopisné dotazy bývají.

Dotazy o slovní zásobě jsou zcela jiné povahy. Jsou přímou reflexí toho, že slovní zásoba dnešní češtiny se prudce mění. Svědectvím nápadných změn je např. nedávné vydání slovníku neologizmů [Nová... 1998], který zachycuje stav nejnovější slovní zásoby, její obohacování přejímáním slov ( $v$ prvé řadě z angličtiny), změnou významů slov i utvářením slov nových. Pracovníci poradny z tohoto slovníku ve svých odpovědích často čerpají, podobně jako z údajů v Českém národním korpusu (www.ucnk.ff.cuni.cz). V dotazech jazykové poradně jde o nejrůznější aspekty uživání slov, o vhodnost, adekvátnost, srozumitelnost při uživání slov v konkrétních textech (franšiza, hardware, software, komunitární, inženýring, management,...) aj.

V pořadí třetí velkou skupinou dotazů jsou dotazy týkající se ohýbání slov, $10 \%$ ze všech dotazů v dopisech a dokonce $15 \%$ z e-mailových dotazů. To bezprostředně souvisí s dotazy na slovní zásobu: S novým slovem se uživatelé musejí naučit zacházet, musejí vědět, zda a jak slovo skloňovat či časovat, tj. užívat ve všech tvarech, které jsou v jazyce s bohatým tvaroslovím, jako je čeština, k dispozici. Nejde však jen o slova přejatá. I tvary běžných českých slov bývají předmětem dotazů (manželi i manžely, oni sázejí i sází, v(e) městě Nymburk, Nymburku i Nymburce,...). 
Tab. 4. Vztah mezi profesí tazatele a druhy jeho jazykových dotazů

tazatelská skupina/druh dotazu

\begin{tabular}{cccccc}
\multicolumn{3}{c}{ pravopis } & \multicolumn{3}{c}{ slovní zásoba } \\
dopisy & e-maily & \multicolumn{2}{c}{ dopisy } & e-maily \\
četnost $\%$ & četnost $\%$ & četnost $\%$ & četnost $\%$ \\
\hline
\end{tabular}

\begin{tabular}{lrrrrrrrr}
\hline soukromí/neidentifikovaní tazatelé & 173 & 40,90 & 153 & 48,88 & 290 & 58,23 & 174 & 60,00 \\
anonymní tazatelé & 0 & 0,00 & 2 & 0,64 & 0 & 0,00 & 3 & 1,03 \\
právníci & 2 & 0,47 & 2 & 0,64 & 25 & 5,02 & 0 & 0,00 \\
sekretáŕky & 11 & 2,60 & 10 & 3,19 & 0 & 0,00 & 6 & 2,07 \\
učitelé, profesoři všech stupňů škol & 34 & 8,04 & 18 & 5,75 & 7 & 1,41 & 13 & 4,48 \\
novináři, redaktoři, korektoři & 53 & 12,53 & 30 & 9,58 & 13 & 2,61 & 10 & 3,45 \\
spisovatelé, překladatelé & 10 & 2,36 & 3 & 0,96 & 12 & 2,41 & 10 & 3,45 \\
žáci, studenti, jejich (pra)rodiče & 10 & 2,36 & 8 & 2,56 & 12 & 2,41 & 17 & 5,86 \\
soukromí podnikatelé & 3 & 0,71 & 5 & 1,60 & 6 & 1,20 & 2 & 0,69 \\
individuální tazatelé různých profesí & 19 & 4,49 & 29 & 9,27 & 40 & 8,03 & 34 & 11,72 \\
společnosti typu s. r. o., a. s. aj. & 17 & 4,02 & 10 & 3,19 & 20 & 4,02 & 6 & 2,07 \\
ostatní instituce & 14 & 3,31 & 9 & 2,88 & 11 & 2,21 & 6 & 2,07 \\
obecní aj. úr̆ady státní správy & 50 & 11,82 & 12 & 3,83 & 23 & 4,62 & 9 & 3,10 \\
soudy, policie & 2 & 0,47 & 1 & 0,32 & 13 & 2,61 & 0 & 0,00 \\
školy všech typů & 17 & 4,02 & 4 & 1,28 & 13 & 2,61 & 0 & 0,00 \\
nakladatelství, tiskárny, rekl. agent. & 8 & 1,89 & 17 & 5,43 & 13 & 2,61 & 0 & 0,00 \\
\hline celkem & 423 & 100,0 & 313 & 100,0 & 498 & 100,0 & 290 & 100,0
\end{tabular}

Vraṫme se ještě jednou k četnostem dotazů uvedeným v tabulce 1. Četnosti zde uvedené vyjadřují průměrné tazatelské zájmy klientů jazykové poradny. „Průměrný“ tazatel je však pouze jistou statistickou abstrakcí, vyjadřující jedno možné shrnutí jazykových zájmů té části populace českých mluvčích, která svůj aktivní zájem o jazyk dává najevo svými dotazy v jazykové poradně. Neznamená to však, že všichni tazatelé jazykové poradny mají stejné jazykové problémy. Data v tabulce 4 ukazují, že tazatelské priority jsou do značné míry profesně podmíněny. Potvrzuje se dlouholetá empirická zkušenost, že pravopisné dotazy často kladou osoby z těch tazatelských skupin, které primárně zacházejí s psanými texty, tedy ty, které především pocitují ve své každodenní praxi závaznost Pravidel českého pravopisu. Dopisy s pravopisnými dotazy dostáváme nejčastěji od novinářů, redaktorů, editorů a korektorů (13\%), dále od autorů úředních, administrativních dokumentů různé právní síly, kde je důležité dodržení jednoty pravopisných principů (12\%), a konečně od učitelů, kteří učí pravopisu na všech stupních škol (8\%). E-maily s pravopisnými dotazy posílají vedle novinářủ ( $10 \%$ ze všech tazatelů) stejně často také jednotliví tazatelé různých profesí ( $9 \%$ ). Naproti tomu existují velké tazatelské skupiny s dominantním zájmem o slovní zásobu. Jsou to především skupiny tazatelů, kteří sami texty tvoří, překládaji (mj. např. v souvislosti se vstupem České republiky do Evropské unie), interpretují, ev. analyzují jejich obsah, tedy specialisté různých profesí v souvislosti s terminologií toho kterého oboru (ti tvoří dohromady $8 \%$ ze všech tazatelů zajímajících se o slovní zásobu v dopisech a dokonce $12 \%$ z těch, kteří kladou tvaroslovné dotazy po e-mailu). Kvantitativní pojem „průměrného“ tazatele, jak o něm byla řeč, se rozpadá při nejmenším na dva pojmy podle toho, která jazyková oblast je onou centrální zájmovou oblastí - bud’ je to pravopis, nebo slovní zásoba; podrobněji viz [Uhlírová 1999a]. 


\section{Jazyková poradna ještě jednou}

Jazyková poradna slouží všem, kdo považují užívání spisovné, resp. šíře: kultivované variety češtiny ve veřejné komunikaci psané i mluvené za náležité (vhodné, komunikujícími partnery očekávané), tj. za takové, které přispívá k úspěšnosti komunikace. Tito uživatelé se obracejí na poradnu, aby jim pomohla vyřešit jazykové problémy, s nimiž se setkávají, když vstupují do nejrůznějších komunikačních situací, na jejichž zvládnutí jim záleží. Jde jim nejen o to, že jazyk je významná kulturní hodnota, ale mnohem více o to, že znalost jeho norem a jeho kultivované uživání je důležité pro jejich práci, že jim přinese společenský prospěch, užitek, úspěch. Pracovníci reklamních agentur si uvědomují, že pravopisná chyba v textu reklamy může být antireklamou pro jejich výrobek, pravopisné chyby neodstraněné při korekturách knihy mohou odsoudit knihu k prodeji ve výprodejích atd. $\mathrm{V}$ různých komunikačních situacích a v různém profesním prostředí vznikají, jak jsme doložili výše, různé jazykové problémy.

Pro pracovníky poradny není podstatné, že tazatel má nějaký jazykový problém, že něco neví. Důležité je, že si je problému vědom, že ho dokáže (více či méně přesně) identifikovat a formulovat, že má zájem dozvědět se „správné“ řešení problému, tedy takové řešení, které je v souhlase s normou, resp. s kodifikací, a že je ochoten takové řešení přijmout a ř́idit se jím.

Lingvisté diskutují o tom, do jaké míry má (může, měla by) lingvistika jako věda o jazyce být disciplinou regulující užívání jazyka a do jaké míry by měla jazyková fakta jen registrovat a popisovat. Názory se přitom různí; podrobněji o tom viz analytickou studii [Daneš 1996].

Pokud bychom rozdělili názory na „více preskriptivni“ (či „regulativni“) a „více deskriptivní, pak úloha jazykové poradny jakožto instituce poradní je v principu regulativní, a to „doporučujíci“. Požadavkům tazatelské veřejnosti je schopna se pružně přizpůsobovat a modernizovat formy poradenské činnosti. V dnešní době, kdy se opakovaně poukazuje na oslabování pozice spisovného standardu (někdy i na oslabování autority bohemistických pracovišt'), můžeme považovat za pozitivní signál, že zavedením poradny na internetu výrazně stoupá zájem o její služby.

LuDMILA UHLírová je vědecká pracovnice Ústavu pro jazyk český AV ČR. Hlavní vědecké zájmy: jazyková kultura, sociolingvistika, statistické modelování jazyka a řeči, česká, slovanská a obecná syntax a slovosled. Spoluautorka syntaktického svazku Mluvnice češtiny (Praha: Academia, 1987), spoluautorka kontrastivní monografie Slovanská věta (Praha: Euroslavica, 1996), spoluautorka monografie Kvantitativní charakteristiky současné češtiny (Praha: Academia, 1985) a řady frekvenčních slovníkủ češtiny. Napsala Knížku o slovosledu (Praha: Academia, 1987). Je autorkou několika desítek statí publikovaných česky, anglicky, německy a bulharsky doma i v zahraničí. V současné době vede oddělení jazykové kultury a gramatiky v ÚJČ a je řšsitelkou, spolurešitelkou nebo členkou řšitelských týmů několika projektů domácích i mezinárodních. 


\section{Literatura}

Aktuální otázky jazykové kultury v socialistické společnosti 1979. Praha: Academia.

Černá A. 1999. „Telefonáty v jazykové poradně a jejich databáze, pokus o sociolingvistický pohled.“ Naše řě 82: 237-244.

Černá, A., Svobodová, I., Šimandl, J., Uhlírová, L. 2002. Na co se nás často ptáte. Praha: Scientia.

Čeština - univerzália a specifika 2, 2000. Z. Hladká, P. Karlík (eds.). Brno: Masarykova univerzita.

Daneš, F. 1996. „Preskripce - anebo ,nechte svůj jazyk na pokoji'?“ Pp. 166-174 in Jazyk a jeho uživání. Praha.

Daneš, F. 1999. Jazyk a text I. Výbor z lingvistického díla Františka Daneše, část 2. Praha: Univerzita Karlova.

Dynamika současné češtiny z hlediska lingvistické teorie a školské praxe 1988. Praha: Univerzita Karlova.

Havránek, B. 1979. „Retrospektivní pohled na jazykovou kulturu.“ Pp. 9-11 in Aktuální otázky...

Hlavsa, Z. 1996. „Kritéria kodifikace.“ Pp. 28-32 in Spisovnost...

Jedlička, A. 1978. Spisovný jazyk v současné komunikaci. Praha: Univerzita Karlova.

Jelínek, M. 1996. „Kritérium systémovosti při kodifikaci spisovné normy.“ Pp. 36-42. In Spisovnost...

Kraus, J. et al., 1981. „Současný stav a vývojové perspektivy kodifikace spisovné češtiny.“ Slovo a slovesnost 42: 228-238.

Krčmová, M. 2000. „Termín obecná čeština a různost jeho chápání.“ In Čeština - univerzália 2: 63-77.

Kultura českého jazyka 1969. Liberec: Severočeské nakladatelství.

Nebeská, I. 1996. Jazyk, norma, spisovnost. Praha: Univerzita Karlova.

Nekvapil, J. 2000. „Language management in a changing society.“ Pp. 165-177 in Panzer, B. (ed.), Die sprachliche Situation in der Slavia zehn Jahre nach der Wende. Frankfurt am Main: Peter Lang.

Neustupný, J. 1999. „Sociolinguistics and the Prague School.“ Pp. 275-286 in Travaux du Circle Linguistique de Prague 3, Prague Linguistic Circle papers. Vol. 3. Amsterdam: John Benjamins.

Nová slova v češtinè 1998. Praha: Academia.

Palková, Z. 1995. „Spisovný standard jazyka v mluvené komunikaci.“ Pp. 76-80 in Spisovná čeština...

Pravidla českého pravopisu, školní vydání 1999. Praha: Fortuna.

Rusínová, Z. 2000. „Jak je to s obecností obecné češtiny.“ Pp. 79-83 in Čeština - univerzália 2.

Sgall, P., J. Hronek 1992. Čeština bez př́kras. Praha: H\&H.

Spisovná čeština a jazyková kultura 1993 1995. Praha: Filozofická fakulta Univerzity Karlovy.

Slovník spisovné češtiny pro školu a veřejnost 2000. Praha: Academia.

Spisovnost a nespisovnost dnes 1996. R. Šrámek (ed.). Brno: Sborník prací Pedagogické fakulty Masarykovy univerzity v Brně, Řada jazyková a literární č. 27.

Stich, A. 1969. „Současné úkoly jazykové kultury.“ Pp. 103-112 in Kultura...

Stich, A. 1995. „Česká spisovnost a nespisovnost - kořeny a přitomnost (Naše postoje k češtině 17. a 18. století).“ Pp. 49-56 in Spisovná čeština...

Svobodová, I. 2000. „O psaní velkých písmen.“ Naše řeč 83: 17-29.

Svobodová, I. 1999. „Poznatky z jazykové poradny jako jedna z možností poznání současného stavu češtiny.“ Jazykovědné aktuality XXXVI: 26-28. 
Šimandl, J. 2000. „Morfologická problematika v jazykové poradně.“ Naše řeč 83: 57-76, 113-131, 169-192, 225-242.

Uhliŕrová, L. 1996. „Archivace lingvistických dokumentů na počítači I a II.“ Naše řeč 79: 171-186, 225-237.

Uhliřrová, L. 1998a. „Linguists vs. the Public: An Electronic Database of Letters to the Language Consulting Service as a Source of Sociolinguistic Information.“ Journal of Quantitative Linguistics. Vol. 5: 262-268.

Uhliřová, L. 1998b. „O dialogu mezi jazykovou poradnou a veřejností aneb K čemu slouží počítačová databáze dotazů o jazyce a odpovědí na ně.“ Slavia, 67: 169-177.

Uhliŕrová, L. 1999a. „O co se zajímají ti, kdo posílají dopisy, faxy a e-maily jazykové poradně?“ Naše řeč 82: 225-236.

Uhliřrová, L. 1999b. „Jazyková poradna pro rok 2000.“ Slovo a slovesnost 60: 241-246.

Uhliřrová, L. 2001. „Internetový dialog jazykové poradny s veřejností (poradna@ujc.cas.cz).“ Naše reč 84: 1-15.

\section{Summary}

Language Service is regarded here as a dialogue between linguists and the public, and as such, it has two sides, or two directions. On one side, there is the public, who asks, and on the other side, there are the linguists, who answer. Linguists offer authorised advice, help, recommendations etc., concerning language behaviour the public is expected to follow. At the same time, linguists also receive information from the public, because the queries have a linguistic and sociological content. The article presents statistical evidence of several aspects of the Language Service: (a) How many questions do people ask about language? If the clients of the services are grouped according to their social and professional status, and if we can differentiate between professional and other ('private') inquirers, we can see that those who ask questions somehow connected with their professional work in a public sphere of communication prevail over those which explicitly arise from private communication and out of an individual's private interest in language as such. Respecting language norms is NOT just a private matter of an individual's language culture; it is much more of a challenge for those who care for social prestige and professional success. (b) The two most frequent subjects of the queries are spelling and vocabulary; the main reasons for this are mentioned in the article. (c) There seems to be a correlation between the frequency of queries and the professional sphere from which the queries come.

The data presented in the article are based on an electronic database of letters from the public and answers to them, which started ten years ago in the Czech Language Institute. The period involved is from 1 January 1992 to 1 September 2001. The traditional way of written correspondence is compared to a new, electronic one, launched in 1999. The Language Service on the Internet has introduced not only a completely different way of communication with inquirers, it has strongly influenced the organisation of service activities. Last but not least, completely new electronic genres have emerged - the e-mail question and the e-mail answer. 